mainly slight. There were no correlation between enzymatic activity and the clinical stage of cervical cancer, and correlation between the enzymatic activity of the cancer tissue and frequency of delivery.

\title{
References
}

1) W. Montagna ; J. Biophysic. and Biochem. Cytol. Vol. 3 343-348 $1957 . \quad 2)$ J. S. Friedenwald and B. Becker; J. Cell. Comp. Physiol. 31 303-310 1948. 3) J. F. Burton and A. G. E. Pearse ; Brit. J. exp. Path. 33 87-97 1952. 4) A. M. Seligman, K. L. Tsou, S. H. Rutenberg and R. B. Cohen ; J. Histochem. and Cytochem. 2 209-228 $1954 . \quad 5)$ W. H. Fishman, J. R. Baker and P. R. F. Borgen ; Cancer. 12 240-245 $1959 . \quad$ 6) O. BraunFalco; Arch. klin. exp. Dermato. 203 68-72 $1956 . \quad 7)$ M. Izuo and K. Oota ; Jap. J. Cancer. Clin. 4 364-370 1958. 8) K. Oota and M. Izuo ; Jap. J. Cancer. clin. 4 356-363 1958. 9) K. Kawakatsu, M. Mori, M. Deguchiand M. Murakami ; J. Jap. stm. Soc. 9 261-267 1960. 10) M. Deguchi ; Arch. histo. japon. 21 41-60 1960. 11) A. Tabuchi, and K. Moriwaki ; Jap. J. Cancer. Clin. 3 806-811 1957. 12) T. Tanase ; IGAKU NO AYUMI. 42 232-236 1962. 13) N. Sinagawa, S. Morita and S. watanabe. Jap. J. Caneer. clin. 5 579-583 1950.

\section{Histochemical Studies on the Regenerated Adrenal Cortex ${ }^{*}$}

\author{
Ryuei Maeda, Reiko Takada, Ichiro Yamagata \\ and Tatsuji Hagrhara
}

The First Department of Pathology (Prof. R. Maeda), Kansai Medical School, Osaka, Japan

* Aided by the Grant in Aid for Fundamental Scientific Research of the Ministry of Education

In a preceding paper ${ }^{6)}$ the assumption that the sudanophilic granules in paraffin section of rat adrenals fixed with Tellyesniczky's fluid contain corticoids, has been proven to be supported by a successful extraction of corticoids from sudanophilic components of bovine adrenals, or of corticoids administered in the subcutaneous tissues of rats fixed with Tllyesniczky's fluid.

Much has been discussed ${ }^{7)}$ on the significant role of enzymes in the formation of corticoids from cholesterol in the adrenal cortex. An attention has been directed on the relationship between endocrinological function of the adrenal cortex and enzymic action. While the reports on adrenal enucleation have been made a number of times ${ }^{2}$, hardly any on the histochemical study on the enzymes especially of oxidative enzymes in regenerated adrenocortical tissue. To test these enzymes, the present investigation is concerned with the active regenerating cortical cells and combined with the staining method of Heidenhain iron hematoxylin Sudan. ${ }^{\text {s) }}$ 


\section{Materials and Methods}

The adrenal tissues were obtained from forty male Wistar rats aged 2-4 months fed regular laboratory diet and acclimated to our animal room for at least a week. The experimental method used was bilateral adrenal enucleation of the rats and 10 case examples were taken from those of 5 post-operative days, one week, 10 days and two weeks respectively. Regenerated adrenal tissues were freshly sectioned by freezing at $-20^{\circ} \mathrm{C}$. with the use of cryostat. The remaining parts were partly treated with the modified carbowax fixing and embedding procedure and partly sectioned after fixed with Tellyesniczky's fluid for Heidenhain-Sudan method. ${ }^{\text {s) }}$

The histochemical techniques referred were as follows: Nachlas et al. method $^{8)}$ for succinic dehydrogenase. Scarpelli et al. method ${ }^{9)}$ for DPN diaphorase, Hess et al. method for DPN-liked diaphorase (lactic, malic, glutamic, $\alpha$ glycerophosphate and alcohol), Levy et al. modification of wattenberg's method ${ }^{103}$ for steroid- $3 \beta$-ol dehydrogenase and Hess et al. method $^{3)}$ for TPN-linked dehydrogenase (isocitric and glucose-6-phosphate). The control staining without any substrate was used in every case in order to exclude the "nothing dehydrogenase". ${ }^{11}$

\section{Results}

As early as five days after the adrenal enucleation, a numder of oxidative enzymes were either weakly or moderately positive in the regenerating adrenocortical cells. With the Heidenhalin-Sudan method, new cell growth of young celluar groups which could be called "germinal layer" were found in the perivascular area in the inner layer of adrenal capsule and also the subcapsular zone. The nuclei of these young cells were rich in chromatin and cell bodies were poorly supplied with sudanophilic granules. Specific oxidative enzymes were present though weakly positive. The enzymatic activities seemed to increase steadily as the cellular regeneration progresses with a period of time, from 5 post-operative days up to 2 weeks duration. Among these glucose6 -phosphate dehydrogenase and steroid $3 \beta$-ol dehydrogenase not only have shown more active reaction but also were stricted to the cells of the regenerated cortical layer. Oxidative enzymes other than the above two seemed to be present though weakly reacted in the periadrenal fat tissue.

\section{Discussion}

From the findings presented, glucose-6-phosphate dehydrogenase and steroid- $3 \beta$-ol dehydrogenase may be presumed to bear a close relationship to function of the regenerated adrenocortical cells. Since glucose-6-phosphate dehydrogenase system is a potential provider of TPNH, a reductant which is important in steroid synthesis, predominant activity of this enzyme in a regenerated adrenocortical layer is greatly noticeable.

On the other hand, activities of steroid- $3 \beta$-ol dehydrogenase are said to be demonstrable in the steroid-secreting cells in the adrenal, testis and ovary but 

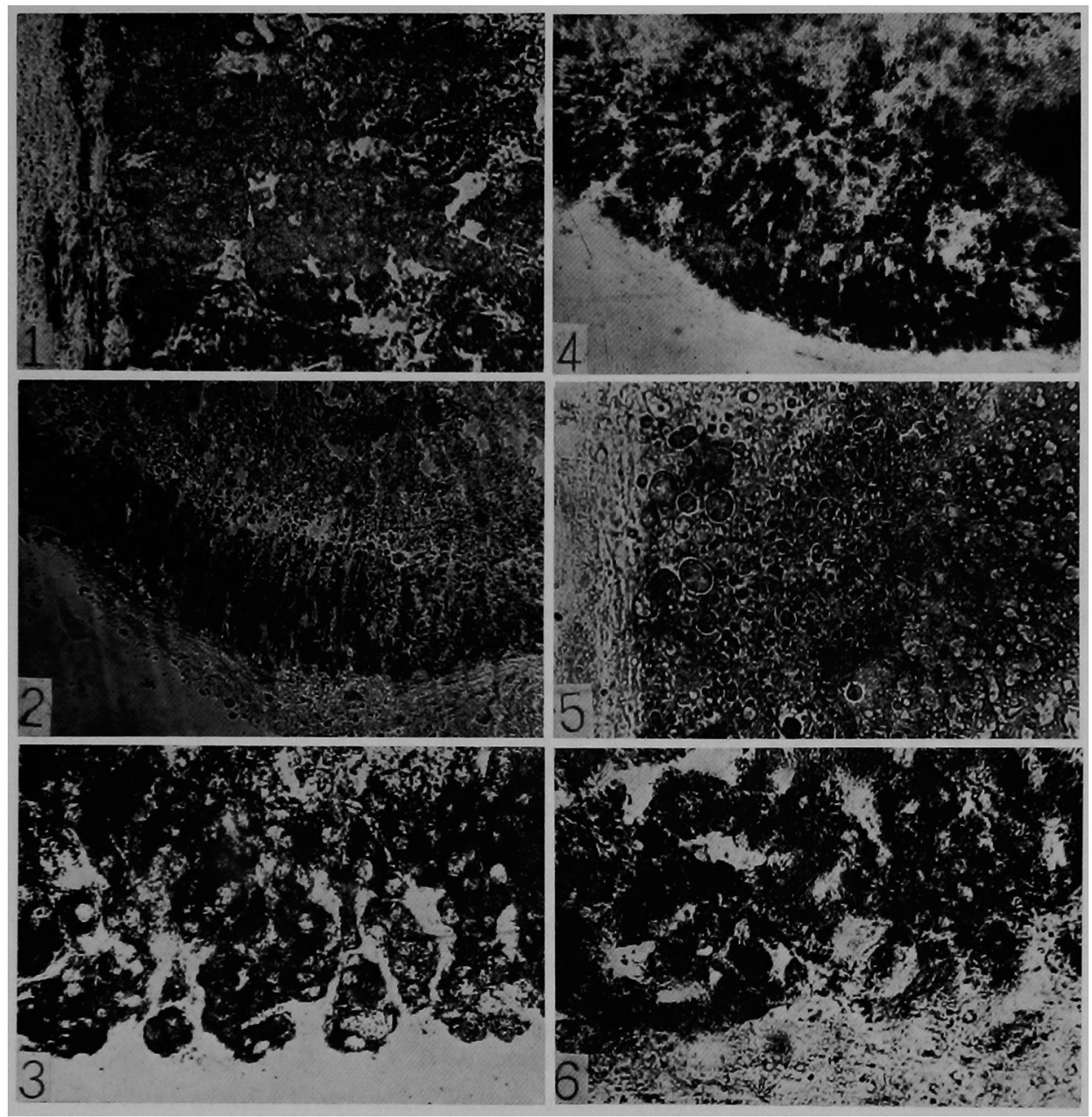

Fig. 1 Portion of rat adrenal on the 5 th day after enucleation; steroid- $3 \boldsymbol{\beta}$-ol dehydrogenase. The cytoplasm of regenerated adrenocortical cells is intensely stained. Moderate activity is present in the perivascular area in the capsular inner layer and the subcapsular zone corresponding to "germinal layer."

Fig. 2 Portion of rat adrenal enucleated for 5 days ; steroid- $3 \beta$-ol dehydrogenase ; low magnification. The findings are similar to those seen in Fig. 1.

Fig. 3 Portion of rat adrenal enucleated for 5 days; glucose-6-phosphate dehydrogenase. The cytoplasm of regenerated adrenocortical cells is deeply stained. The capsule is entirely unstained.

Fig. 4 Portion of rat adrenal enucleated for 2 weeks ; glucose-6-phosphate dehydrogenase ; low power. A regenerating adrenocortical layer shows the deposition of abundant amouts of the formazan particles.

Fig. 5 Portion of adrenal gland of a normal male rat; glucose-6-phosphate dehydrogenase. The formazan pigment is moderately deposited in the cytoplasm of adrenocortical cells, except in fatty granules.

Fig. 6 Portion of rat adrenal on the 5 th day after enucleation. Moderate activity of $\alpha-$ glycerophosphate dehydrogenase is recognized in a regenerating adrenocortical layer. Note the weak staining of the capsule. 
not in the kidney or liver sections not implicated in steroid synthesis where activities of other types of oxidative enzymes are most frequently detectable.

It is of marked interest to know the fact that the above two enymes were detectable in a short duration of five days after adrenal enucleation, since our experimental observations seem to sugget early synthesis of steroid hormone in the regenerating adrenal cortex.

\section{Summary}

Enzymic activities have been demonstrated in the regenerating adrenal cortex five days after bilateral enucleation of the adrenals. The activities seemed to be increasingly enhanced as the days elapsed though weakly positive. It was found that above all steroid- $3 \boldsymbol{\beta}$-ol dehydrogenase and glucose-6-phosphate dehydrogenase showed most marked action in the cells confined to the cortical zone. It is assumed that there seemed to be apparent relationship between function of adrenocortical steroid metabolism and activity of the above two enzymes.

\section{References}

1) Cohen, R. B., Proc. Soc. Exper. Biol. \& Med., 101, 405-407, 1959 . 2) Greep, R. O. and Deane, H. W., Endocrinology, 45, 42-56, 1949. 3) Hess, R., Scarpelli, D. G. and Pearse, A. G. E., J. Biophys. \& Biochem. Cytol., 4, 753-760, 1958. 4) Levy, H., Deane, H. W. and Rubin, B. L., Endocrinology, 65, 932-943, 1959. 5) Maeda, R., Takada, R. and Yamagata, I., Folia Endocrinol. Jap., 37, 487-494, 1961. 6) Maeda, R., Takada, R. and Yamagata, I., Proc. Jap. Histochem. Ass., 2nd Annual Meeting, 1961 (in print). 7) 7) Miura, Y., Saishin Igaku, 15, 2216-2220, 1960 (Japanese). 8) Nachlass, M. M., Tsou, K.-C., de Souza, E., Cheng, C.-S. and Seligman, A. M., J. Histochem. \& Cytochem., 5. 420-436, 1957. 9) Scarpelli, D. G., Hess, R. and Pearse, A. G. E., J. Biophys. \& Biochem. Cytol., 4, 747-752, 1958. 10) Wattenberg, L. W., J. Histochem. \& Cytochem., 6, 225-232, 1958. 11) Zimmermann, H. and Pearse, A. G. E., J. Histochem. \& Cytochem., 7, 271-275, 1959.

\section{Discussion}

Dr. A. Mizutani : In histochemistry of various dehydrogenases, especially in case of fresh tissues, some complicated problems on "nothing dehydrogenase", I think it must be emphasized, should be taken into consideration in connexion with substrate specificity of each engyme.

I thnik that G-6-P dehydrogenase is comparatively labile, being of a little different physico-chemieal character from others. How do you think about this compared with the results of your experiments?

Dr. I. Yamagata: In the carbowax sections considerable activity of all dehydrogenases including G-6-P dehydrogenase, histochemically demonstrated in this experiment, have remained within more than 2 months after embedding. Even at the time more than 2 months after embedding no reduction in enzyme activity observed in comparison with those recognized immediately after embedding. All of the slides presented just now show the histochemical findings, activity of each dehydrogenases, of the sections prepared more than 2 months after embedding in carbowax. On the problems on "nothing dehydrogenase" we have made control tests in all cases with negative results and in histochemical demonstration of all enzymes we have simultaneously used not only liver but alse other organs including kidney and muscle. 